\title{
LOGISTICS OF RURAL TOURISM
}

\author{
Snežana Tadić ${ }^{1}$, Miloš Veljović ${ }^{2}$ \\ ${ }^{1,2}$ University of Belgrade, Faculty of Transport and Traffic Engineering, Vojvode Stepe 305, 11000 \\ Belgrade, Serbia
}

Received 4 May 2020; accepted 22 June 2020

\begin{abstract}
Tourism has been developing intensively in recent decades due to various social and economic trends. Rural tourism, which includes various tourist activities in rural areas (tourism in households, ecotourism, recreational, adventure, sports, health, artistic, heritage tourism, etc.) is also gaining in importance. The main instrument for the efficient realization of flows of people, goods and information in the Rural Tourism Supply Chain (RTSC) and increasing the competitiveness of tourism products is logistics. Logistics provides a material and a nonmaterial basis for rural tourism services. As suppliers of raw materials and finished products to other actors, but also as creators of their own tourism offer, households are significant actors in the supply chain and generators of logistics flows in rural tourism. A specific form of rural tourism related to households and agricultural production is called agritourism. This paper analyzes the critical issues and structure of the RTSC, structure the logistics of agritourism and analyzing particular areas in terms of logistics flows, processes, and activities.
\end{abstract}

Keywords: logistics, supply chain, rural tourism, agritourism, household, logistic flows, processes and activities.

\section{Introduction}

Tourism is a social, cultural and economic phenomenon related to the movement of people to places outside their usual place of residence, with pleasure being a common motivation (UN, 2010). A tourism product is a set of available goods, services and amenities that tourists can use to meet their needs in a particular area and over a period of time (Tadić et al., 2012). The growth and development of the tourism sector have been induced in recent decades by various social and economic factors, including: globalization, information and communication technology (ICT) development, transport infrastructure development, better living standards and more leisure time, consumerism and hedonism, offer of new tourist services and amenities etc.

Tourism development generates massive flows of people, their personal belongings, goods and information. The main instrument for efficient realization of these flows is logistics. According to Kochadze et al. (2013) tourism logistics is the science of planning, controlling and manaing operations performed during the process of preparing a tourist offer, delivering the finished product to the customer in accordance with his interests and requirements, as well as during the process of transferring, storing and processing information about these activities. Tourism, like other activities,

${ }^{1}$ Corresponding author: s.tadic@sf.bg.ac.rs 
depends on the efficiency of goods flows, but logistics activities that enable their realization are often ignored and neglected (Tadić \& Zečević, 2016a). Logistics principles, knowledge and technologies should be applied in order to increase the competitiveness of tourism products.

The tourism supply chain (TSC) encompasses suppliers of all goods and services involved in delivering tourism products to customers (Tapper \& Font, 2004). The main intermediaries between users and providers of tourism services are travel agencies and tour operators (Page, 2014; Buhalis \& Laws, 2001; Baloglu \& Mangaloglu, 2001). Agencies sell tourist products, while tour operators also organize logistics activities with the aim of providing the tourist product to the user at the right time at the right place under the most favorable conditions (Tadić et al., 2012; Muhcina \& Popovici, 2008).

Tourism services and activities in rural areas, that do not have an urban character, constitute rural tourism (Lane, 1994). Rural areas are characterized by low population density and small settlement areas, open space, natural environment, dominant land use for agriculture and forestry (Lane, 1994). These areas are affected by the problems of emigration, depopulation, unemployment and poverty. Rural tourism can contribute to the revitalization of the countryside, reducing unemployment, improving living standards and developing the rural economy (Liu, 2006; Sharpley \& Roberts, 2004; Gannon, 1994). Existing material and nonmaterial resources in rural areas, especially natural resources, traditional architecture, agricultural production, gastronomy and cultural heritage, are a valuable basis for tourism developing. The unspoiled nature, the spirit of yesteryear, a slower lifestyle, a healthier environment and food all attract urban people, that burdened with work, weather, stress, city noise and pollution, to the rural areas. Through rest and relaxation in rural areas, the negative effects of these phenomena on human health diminish (Krasavac et al., 2018), so rural tourism also contributes to the functionality of urban areas.

Logistics in rural tourism provides material (warehouses, means of transport, flows of goods, materials, freights, etc.) and nonmaterial basis (promotion, information flows, etc.) for the providing tourist services. Logistics activities are present in the procurement of raw materials, energy and finished products, promotional and sales activities of participants in the supply chain, transportation of tourists and their personal belongings, the process of providing services to end users in catering facilities, the realization of reverse flows of tourist service providers etc.

Rural tourism supply chains (RTSC) have different characteristics depending on the degree of development of the area. In developed areas, catering facilities provide rural tourism services, using products and services of other participants (food producers, marketing and training centers, tour operators and travel agencies, etc.). On the other hand, in underdeveloped areas, rural tourism is most often based on the offer of agricultural households, which independently realize most business processes, often without professional knowledge. The tourist offer of agricultural households is commonly referred to as agritourism/agrotourism (Phillip et al., 2012). As suppliers of raw materials and finished products to other actors, but also as 
creators of their own tourist offer, households are significant actors in the supply chain and generators of logistics flows in rural tourism (Tadić \& Veljović, 2020).

A survey of logistics in tourism has identified a serious lack of relevant literature (Ajagunna et al., 2017; Muhcina \& Popovici, 2008; Mrnjavac \& Ivanovic, 2007). Few papers in the field of logistics in rural tourism and agritourism adress information flows (Niedziółka, 2015) and promotion (Brzozowska et al., 2018; Niedziółka, 2012), but there are no papers that address all logistics subsystems, processes and activities. The area of tourism supply chain management (TSCM) has been significantly better researched (Zhang et al., 2009; Sigala, 2008; Font et al., 2008; Tapper \& Font, 2004), but only a few papers address short (Tanasă, 2014; Hüller et al., 2017), green and sustainable RTSCs (Chen et al., 2018; Mehdi, 2017).

This paper addresses with the characteristics of supply chains and logistics in rural tourism. The aim of the paper is to get acquainted with the structure and processes of different RTSCs and the characteristics of logistic flows, processes and activities of households providing rural/agritourism services. Structuring of agritourism logistics and analysis of particular areas from the mentioned aspects is the basic contribution of the paper. As this area is almost completely unresearched, a significant contribution of the paper is to lay the groundwork for future research. Also, for companies and households in rural tourism, paper can be a series of recommendations for more efficient supply chain management and logistics.

The paper is organized as follows. The conceptual definition, basic characteristics and global status of rural and agritourism are presented below. Chapter 3 addresses with rural tourism supply chain management (RTSCM), its critical issues and structure. Chapter 4 describes the characteristics and structure of logistics of rural tourism and agritourism, as well as the flows, processes and activities of the agritourism household. Finally, concluding considerations and directions for future research are presented.

\section{The Concept and Characteristics of Rural Tourism}

There are many terms related to tourism in rural areas: rural tourism, ecotourism, village tourism, agritourism, agrotourism, farm tourism, farm stay etc. Different interpretations of these terms are present in the scientific literature and in everyday communication, and it is not possible to conclude and delineate them definitively. The relationship between rural and agritourism is especially complex.

In general, rural tourism is the broadest term, encompassing various forms of tourism activities in rural areas: tourism in households, ecotourism, walking, climbing and horseback riding, adventure, sport and health tourism, hunting and fishing, educational, artistic, heritage and ethnic tourism etc. (Lane, 1994). Interest in rural tourism is most pronounced in Western Europe and North America, but in recent decades, rural tourism has developed in other parts of the world (Vuković, 2017). Rural tourism accounts for about $10-25 \%$ of all forms of tourism activity (Park \& Yoon, 2009). In the European Union, in 2018, $30.3 \%$ of overnight stays were realized in rural accommodation (Eurostat, 2019). It is estimated that around half a million people in Europe are directly or indirectly employed in rural tourism (Krasavac et al., 2018). 
There are global differences in rural tourism in terms of the specifics of the offer, the duration of the tourist trip, the degree of development, the supply chains etc. In Europe and Asia and before the development of rural tourism, accommodation services were provided in rural households in winter, when agricultural work was minimal (Ohe, 2008). Such services were most often present in mountainous areas, where hikers and skiers were tourists (Ohe, 2008). Even today, rural tourism in the European Union is related primarily to experiences, people, heritage and lifestyle in the village (Fagioli et al., 2014), but also sports, adventure, entertainment and other amenities in the immediate vicinity. European countries with specific rural tourism offer are Italy, Austria, Switzerland, Germany, Denmark, Spain, the Netherlands and Belgium (Ciolac et al., 2019). Tourism activities in the rural areas of United States include hiking, golf, cycling, hunting, fishing and water sports, visits to beaches, national and state parks, wineries, orchards, and other national amenities (TRIP, 2019).

The duration of a tourist trip depends on sociodemographic and economic parameters (Alegre \& Pou, 2006). In Western Europe, the use of rural tourism services usually involves overnight stays, while in Asia, excursion, daily trips are more prevalent (Park \& Yoon, 2009; Ohe, 2008).

The features of rural tourism also depend on the degree of development of the area. Underdeveloped countries can take advantages of the rural tourism development models of developed countries, but also vice versa. Namely, another specificity of rural tourism is the primacy of sustainability and preservation of existing values in relation to economic development (Krasavac et al., 2018). Rural tourism can be said to be synonymous with sustainable tourism development (Sharpley \& Roberts, 2004). Underdeveloped countries can learn from the developed countries about the efficiency of the organization, technical and technological solutions and information systems, networking and cooperation of actors in the supply chain, professionalism and expertise of rural tourism workers. On the other hand, underdeveloped areas are still characterized by the traditional way of agricultural and food production, the use of natural materials and resources, the high degree of autonomy of agricultural households, and other forms of "positive backwardness" that provide a good basis for rural tourism. The development of rural tourism should be based on the combination of the benefits of these concepts, seeking to respect all three components of sustainable development: economic, environmental and social.

In underdeveloped rural areas, there is a lack of supply chain (Krasavac et al., 2018), while more developed forms of rural tourism imply cooperation, coordination and integration of different entities (travel agencies, tour operators, marketing centers, educational institutions, government, suppliers of products and services etc.) (Chen et al., 2018). The solution to the conflict between environmental goals and gaining economic benefits in rural tourism is the green supply chain, so the entities responsible for the reverse flows should be included in the supply chain (Chen et al., 2018).

The quality of realization of logistics flows, processes and activities also depends on the degree of development of the area. Application of information-communication, transport, storage, agricultural, craft and food production technologies, construction and maintenance of transport infrastructure for different modes of transport, development 
of professional skills of employees, as well as application of logistics principles can significantly contribute to the efficiency of rural tourism logistics.

The form of rural tourism, which relates into households and agricultural production, is called agritourism/agrotourism (Phillip et al., 2010; Kizos \& Iosifides, 2007; Sonnino, 2004; Nilsson, 2002). Undoubtedly, in the broadest interpretation of rural tourism, agritourism activities are an important part of it (Petrović, 2014). Increasingly, agricultural households also carry out tourism activities to further increase income (Park \& Yoon, 2009). Except as an additional activity, households may engage in tourism as their primary activity.

The basic elements of agritourism are: accommodation, food and entertainment (Ciolac et al., 2019). One of the popular agritourism services is participation in activities that take place within the household (Park \& Yoon, 2009). This most often involves doing agricultural and craft jobs. In some areas, the concepts of paid, active holidays are highly developed. Visitors to agritourism households should be able to be: tourists who spend, workers who earn money, or tourists-workers who do not earn or spend, but work one day, to enjoy another day, changing roles. Through the services of rural tourism and agritourism, there is also an opportunity to market agricultural, food, handicraft products and souvenirs.

\section{Supply Chains in Rural Tourism}

TSC is a network of tourism organizations engaged in various activities ranging from offering various components of tourism products/services such as flights and accommodation to distribution and marketing of the final tourism product in a particular tourist destination, and includes a wide range of participants in both the private and public sectors (Zhang et al., 2009). Flows of goods, materials and freights, that are involved in the process of service delivery to the customer, realize in much of the supply chain. Flows of returnable packaging, logistic units and waste also realize. In addition to material products, participants in the supply chain can be supplied with "intangible" products such as education, training and project development. RTSCs may have different characteristics in terms of key business processes, i.e. critical issues (Zhang et al., 2009) and structure (Cooper et al., 1997). These two aspects will be analyzed below.

\subsection{Critical Issues in RTSCM}

Given that end-users are supplied with services and material products, RTSC can be treated as a service supply chain (Boon-itt \& Pongpanarat, 2011; Ellram et al., 2004) or as a traditional supply chain (Lambert et al., 1998; Cooper et al., 1997). The critical issues or business processes in both categories of supply chains are (Sengupta et al., 2006): demand management, customer relationship management (CRM) and supplier relationship management. In addition to these processes, critical issues at RTSCM are: ICT management, two-party relationship management, supply chain coordination, inventory management and product development (Zhang et al., 2009).

Demand management is crucial for the successful implementation of TSCM (Song, 2012; Zhang et al., 2009). Demand in rural tourism depends on economic, promotional, quality and destination factors, and is most often expressed through visitor numbers and 
overnight stays (Roget \& González, 2006). One of the main characteristics of demand in rural tourism is seasonality (Kastenholz \& Lopes de Almeida, 2008). Engaging tour operators and travel agencies in the international promotion and sale of rural tourism services can contribute to increased visitor numbers, occupancy and profitability, but also to a decrease in seasonality of demand (Molina et al., 2010). On the other hand, the increasing prevalence of direct internet sales in some cases eliminates tour operators and travel agencies from the supply chain, as the user independently creates a tourism product from services of his own choosing (Slusarczyk et al., 2016).

CRM harmonizes business processes with customer strategies to achieve customer loyalty and maximize profits (Rigby et al., 2002) by implementing ICT (Ryals \& Knox, 2001). Companies in the tourism sector are increasingly implementing CRM (Özgener \& İraz, 2006). Rural tourism hospitality companies typically apply implicit CMR, which is based on the experience of staff employed and the identification of customer requirements and preferences (Molina et al., 2010). This concept is suitable for households but not for companies with intensive staff rotation (Minghetti, 2003), where it is necessary to implement ICT based CMR. ICTs, especially the Internet, are also used in demand research, promotion, sales, other marketing jobs, collaboration and communication with other actors in the supply chain, in-house organizational communication (Bethapudi, 2013; Molina et al., 2010).

Two-party relationships represent relationships with other entities in the supply chain, including suppliers, distributors, competitors, partners, government and other firms that perform complementary activities in order to operate more successfully and meet customer needs (Song, 2012; Zhang et al., 2009). Creating solid partnerships between actors in the supply chain is of paramount importance for achieving the quality of rural tourism services (Ciolac et al., 2019). There are two types of two-party relations: vertical (between heterogeneous participants: e.g. travel agencies and suppliers) and horizontal (between homogeneous participants: e.g. hotels) (Song, 2012; Zhang et al., 2009). In order to supply chain management and business processes more effectively, horizontal integration, i.e. joining of rural tourism service providers, is increasingly being implemented, especially in the field of ICT implementation (Molina et al., 2010).

Especially important in the supply chain are relationships with suppliers, i.e. procurement management. The costs and quality of business of the companies depend significantly on the supplier (Zhang et al., 2009). Supplier relationship management includes long-term relationships, supplier selection, reduction of supplier base, supplier involvement, and supplier certification (Chen \& Paulraj, 2004).

Supply chain coordination is a pattern of decision making and communication of interrelated participants performing tasks in order to maximize the benefits or the overall profit of the supply chain (Malone, 1987). This requires that each participant perform their tasks by considering the impact of their activities on the other participants (Zhang et al., 2009). Proper cooperation and coordination of different entities in rural tourism is important for differentiating tourism offer (Krasavac et al., 2018). Coordination of catering firms and tour operators is of especially importance (Guo \& $\mathrm{He}, 2012)$. 
TSC can be categorized as a push supply chain, as tourism product production is usually based on demand forecasting, that is, analyzing historical sales data (Tadić et al., 2012; Zhang et al., 2009). Developing effective inventory management strategies is key to overcoming demand variations and achieving effective TSCM.

Product development is a complex process that requires an understanding of customer needs and involves careful analysis of the components and elements of a product to identify potential products that will respond to the ever-changing tastes of consumers (Tadić et al., 2012; Zhang et al., 2009). The goal is to meet customer needs at the right time with the right products (Zhang et al., 2009). Product development requires the joint efforts of different actors in the supply chain and contributes to product quality, reduced production costs and demand variation (Tadić et al., 2012).

\subsection{RTSC Structure}

Different supply chain structures can be observed by analyzing rural tourism in differently developed areas. The simplest model for supplying visitors with a tourism product involves business of agritourism households, independently of other actors in rural tourism. The household independently provides the material and non-material basis for providing tourist service. The material basis is primarily the accommodation capacities of the household, agricultural products, as raw materials for the production of food and beverages, and the work, knowledge and skills of household members as providers of tourist services. Also, agricultural products are directly sold to customers in the household (Krasavac et al., 2018). In this way, the buyer has complete insight into the origin and production process of the products he purchases. This model enables complete autonomy and independence of the household in the management, organization and realization of rural tourism services. On the other hand, the lack of connection with other entities that can participate in the supply chain (professional food producers, education and training centers, marketing companies, reverse logistics providers, etc.) can negatively affect the development of rural tourism. This model actually represents the absence of a supply chain and is most often present in areas with underdeveloped rural tourism.

Rural tourism tends to use local resources. This encourages the sale of products characteristic of the local environment and the earnings of local producers, while reducing the cost of supply and delivery of goods. Therefore, short food supply chain (SFSC) is of especially importance for rural tourism. According to the British organization Soil Association (2001), SFSC is defined as "a system of production, processing and trade, based primarily on organic and sustainable methods of agri-food production, where physical and economic activity is largely carried out and controlled within the locality, or the region where it is produced, which provides health, economic, environmental and social benefits to communities in these areas" (as cited in (Tanasă, 2014)). This supply chain can be called short in terms of territorial coverage and number of participants. The advantage of short supply chains, as well as in the absence of a supply chain, is to inform consumers about the origin and quality of the product (Krasavac et al., 2018; Hüller et al., 2017). In such supply chains, rural tourism service providers do not produce the food consumed by tourists but is sourced from local producers. Fig. 1 shows an example of a short RTSC. This chain is made up of raw 
material suppliers, small food producers, tourism-catering and trading companies, through which products reach customers (Hüller et al., 2017).

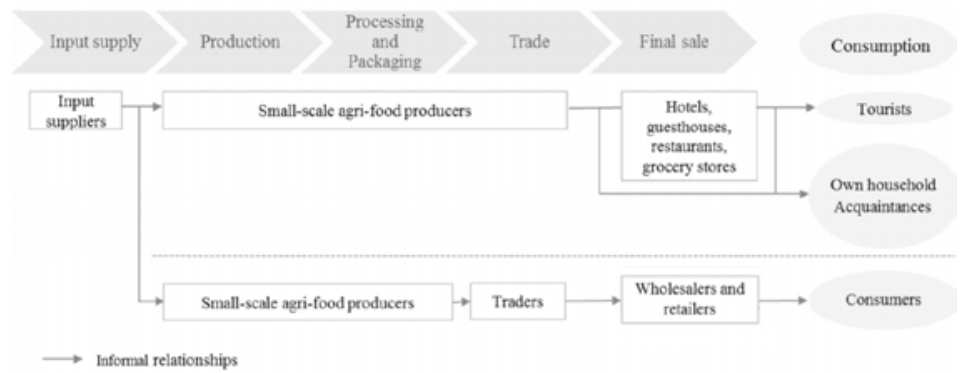

Fig. 1.

An Example of a Short RTSC

Source: (Hüller et al., 2017)

Fig. 2 shows the complex structure of the TSC, as it may be in rural tourism. Browsing the literature revealed a significant role of tour operators in TSC (Page, 2014; Tadić et al., 2012; Sigala, 2008; Baloglu \& Mangaloglu, 2001). Tour operators purchase services (e.g. transport, accommodation, food, entertainment) from the first tier of suppliers (carriers, agritourism households, farms, restaurants, hotels and other rural tourism service providers) and create tourist products for sale to customers directly or through travel agencies (Tadić et al., 2012; Ujma, 2001). In this way, tour operators play a key role in supply chain management. Direct suppliers of tourism services are supplied by second and third tier of suppliers, referred to as indirect suppliers. Indirect suppliers include food and beverage manufacturers, furniture and equipment manufacturers, handicraft manufacturers, water and energy suppliers etc. (Tadić et al., 2012).

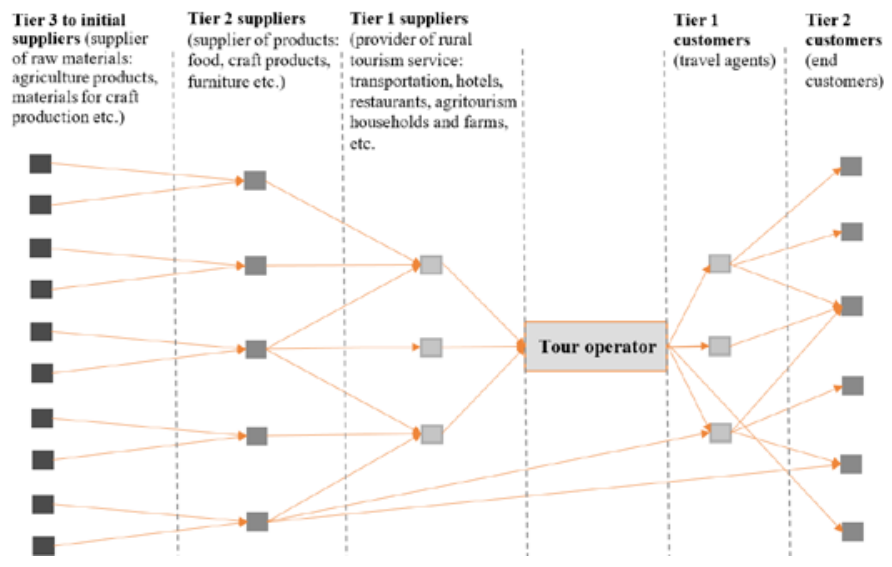

Fig. 2.

An Example of a Complex RTSC

Source: revised (Tadić et al., 2012) 
A similar RTSC structure is defined by Chen et al. (2018), supplementing it with participants relating to reverse flows and "intangible" products. In this way, the most complex RTSC model is established, which has the character of a green supply chain (Fig. 3). "Intangible" products of the first and second tier of suppliers are provided by training centers, marketing corporations, local government, non-profit organizations, educational institutions etc.
(Chen et al., 2018; Xu \& Znou, 2009). Since the green supply chain is proposed as a solution to the conflicting goals of economic development and environmental sustainability, reverse logistics providers, environmental protection and waste recycling and disposal centers are included at various tiers. Thus, the supply chain consists of material product flows, service flows and reverse logistics flows (Chen et al., 2018).

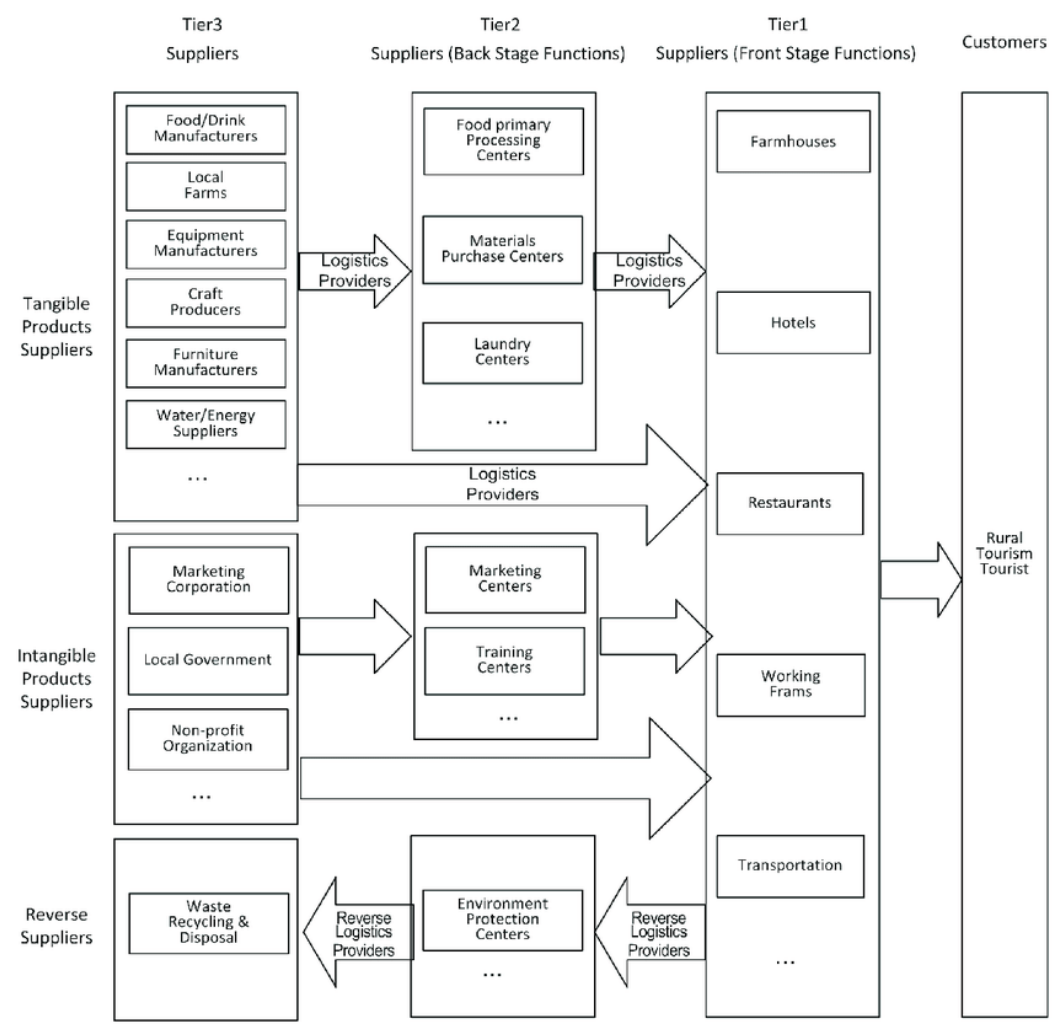

Fig. 3.

An Example of a Green RTSC

Source: (Chen et al., 2018) 


\section{Logistics of Rural Tourism}

Due to the development of tourism in rural areas, the complexity of logistics chains, participants and flows is increasing. Logistics plays a role in the planning, organization and realization of processes and activities both within supply chain companies and in their interactions. It provides a material and non-material basis for tourism services. Sales, promotional activities and information flows are non-material basis. On the other hand, material basis for services consists of warehouses, means of transport, flows of goods, materials and freights. Perishability is one of the basic features of tourism services, since they are used at the time of creation and cannot be stored for future use (Tadić et al., 2012; Zhang et al., 2009; Zeithaml et al., 1985), so the importance of logistics is crucial in the timely implementation of activities and processes in rural tourism.

Households providing rural tourism, that is, agritourism services are a significant generators of logistics flows (Tadić \& Veljović, 2020), so the characteristics and structure of agritourism logistics will be presented below. Research in the field of rural tourism logistics address the agritourism aspect, but there is no comprehensive and generally accepted definition. According to Adamchevskaya (2016) logistics in agritourism comes down to the concept just in time, so its main role is to increase the accuracy and timeliness of delivery of goods or to bring people to an agritourism destination by various modes of transport. Brzozowska et al. (2018) consider logistics to be a very important factor in the development of agritourism, but above all emphasize the importance of efficient information flow on tourism services provided by households.

However, the agritourism logistics is much more complex and is represented in all activities of preparation, promotion and realization of tourist services. The material basis for the provision of agritourism services consist of the flow of goods, materials and freights, warehouses, agricultural and accommodation facilities, elements of interior and exterior of the household. Unlike other catering facilities in rural tourism, households most often use existing capacities adapted to the new purpose. Agritourism logistics consists of (Fig. 4): logistics of household preparation for agritourism, logistics of procurement of goods and natural raw materials for services and production, logistics of household production, reverse logistics and waste management, logistics of promotion, events and sales and logistics of agritourism services. It is desirable that one or more members of the household take over responsibility for one or more areas of agritourism logistics, acquire and refine knowledge and experience especially in those (these) areas, but inevitably also know processes in other areas. 


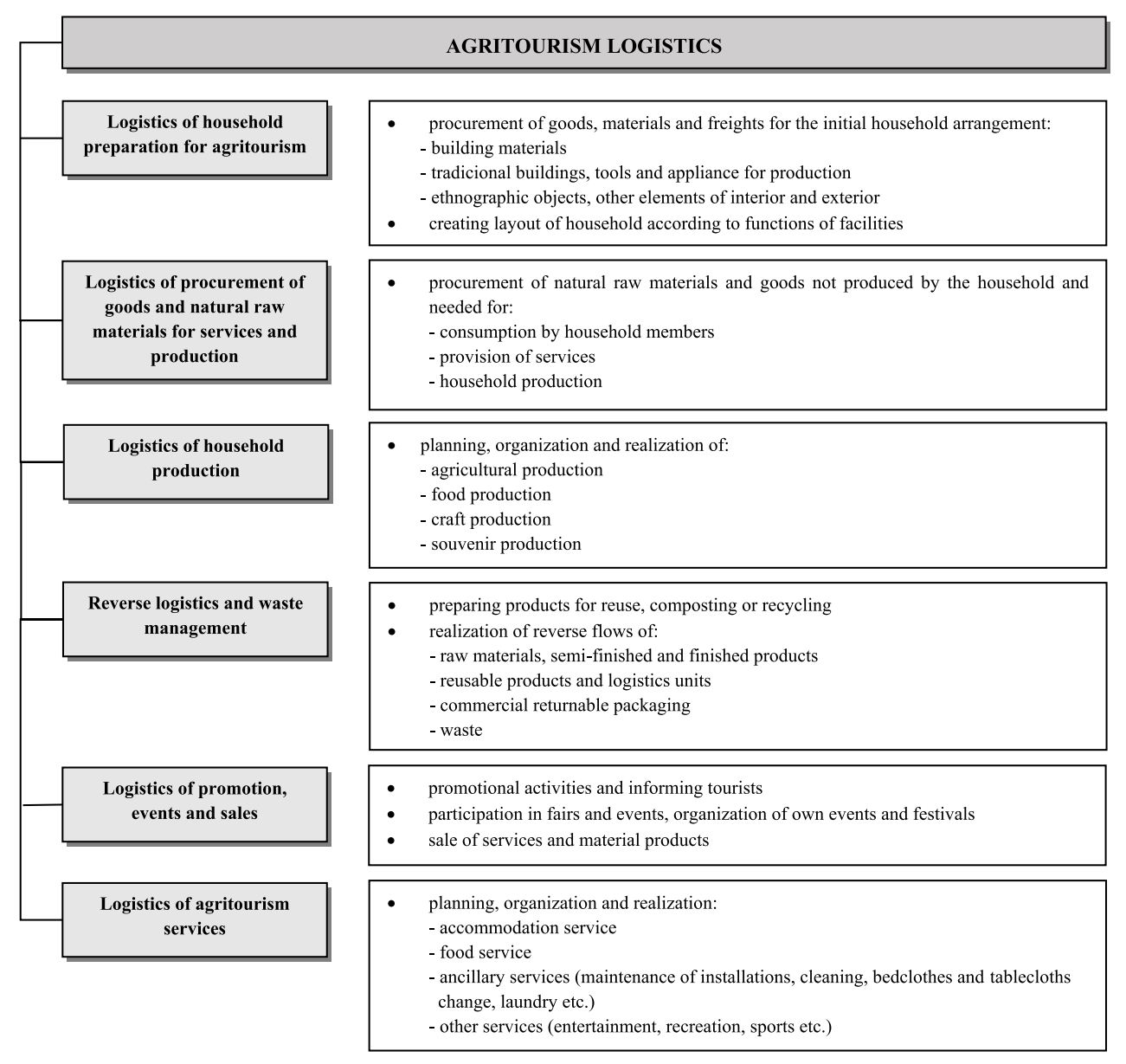

Fig. 4.

Structure of Agritourism Logistics

Each area of agritourism logistics is characterized by a large number of different logistics flows. Household flows are divided into input, output and internal (Tadić \& Veljović, 2020). Input flows include delivery, output flows shipping of goods, materials and freights, and internal flows are realized within and between different units owned by the household. Flows vary in size, frequency, structure of goods, materials and freights, time of realization etc. (Tadić \& Veljović, 2020; Tadić \& Zečević, 2016a; Tadić et al., 2014; Zečević \& Tadić, 2006). Traditional flows generated by an agricultural household involve supplying the market in urban areas with goods produced by household (Tadić \& Veljović, 2020; Gebresenbet \& Bosona, 2012). Due to the development of agritourism and offer of agricultural products, a new type of flows is generated, which are going in the opposite direction (Ohe, 2008). Namely, people from cities come to rural areas to buy service or material products offered by households. 
These are agricultural, food, craft products and souvenirs, as well as tourist services: accommodation, food, entertainment, etc. Now, as end users, citizens are also realizers of the flow of goods between rural and urban areas. Therefore, they pay the transport costs of flow realization. In addition to the usual supply flows of goods and nature raw materials, return flows, waste flows, internal flows of household production, flows of goods for sale produced by household, service flows etc. (Tadić \& Veljović, 2020), agritourism household realizes supply flows of goods, materials and freights for initial household arrangement, information and promotional material flows, internal service flows, sightseeing tours, etc. (Fig. 5).
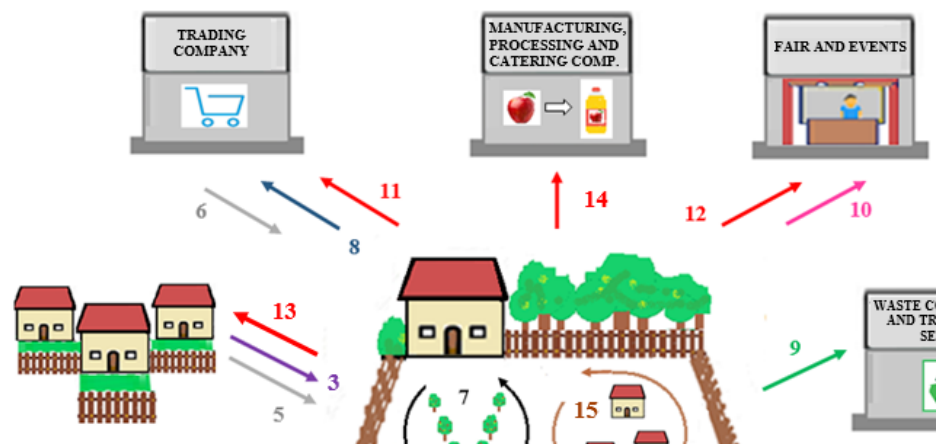

14

8

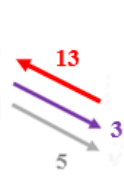


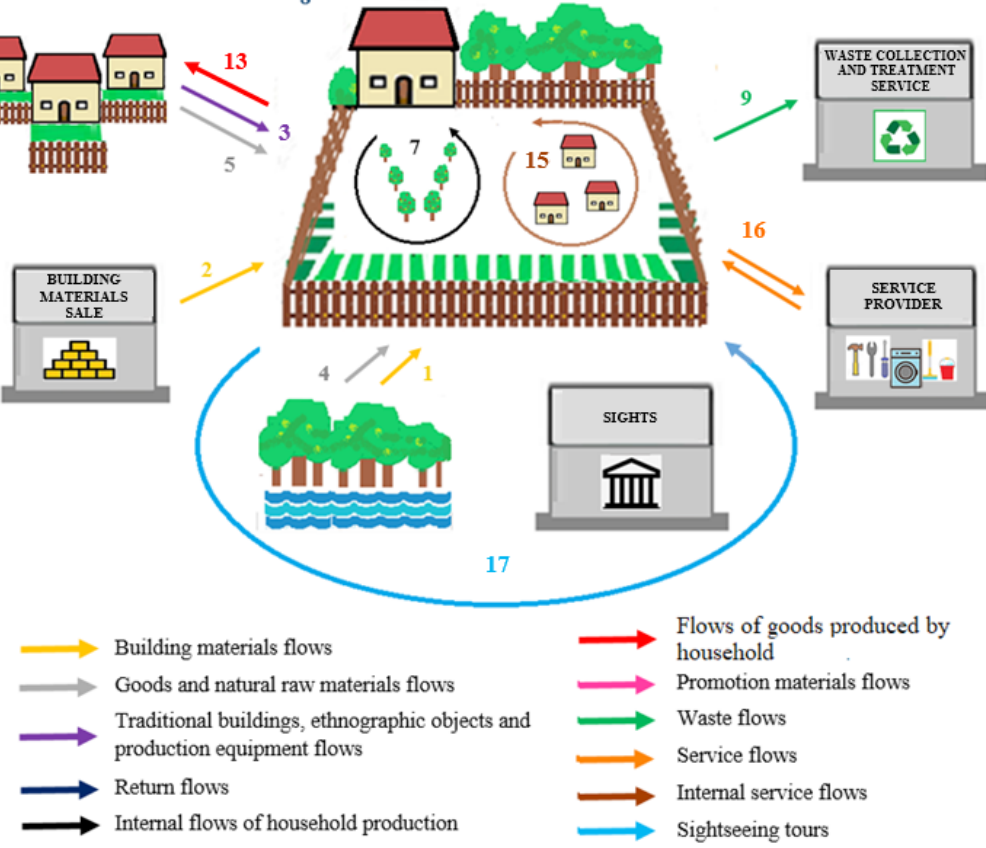

Fig. 5.

Logistics Flows of Agritourism Household

The household logistics system can have traditional characteristics, thus completing the ambience in which agritourism activities take place. The application of all traditional methods of packaging (packaging units made of natural materials: wood, clay, etc.), storage (storage without equipment and with traditional equipment: shelves, 
wooden bulkheads, etc.) and transport (the carriage, working animals, etc.) that meet the criteria of logistical functionality and cost-effectiveness, as well as contemporary environmental and health imperatives. On the other hand, the use of advanced technical and technological solutions is indispensable in planning the efficient logistics of an agritourism household.

\subsection{Logistics of Household Preparation for Agritourism}

The household can be prepared for tourism by adapting existing and/or creating new capacities. The role of logistics in the initial arrangement of the household relates to the procurement and layout of elements that will enable its functionality. This primarily refers to: the procurement of building materials, construction, adaptation or equipping of buildings and yards, the procurement and spatial arrangement of traditional buildings, tools and appliances for production, furniture, ethnographic objects etc. In the initial arrangement of the household, efforts should be made to utilize the existing resources and potentials of the household and its immediate environment.

In the period of initial household arrangement, high frequency and large volume input flows are realized. The most intensive are the flows of building materials (Tadić \& Veljović, 2020), which also can be realized later, during the construction, reconstruction, rehabilitation or demolition of buildings, but at that time they are much smaller in frequency and volume. Building materials can be exploited from nature (Fig. 5, Flow 1) or purchased (Fig. 5, Flow 2). Logistics costs can be reduced by using locally available building materials, and in this way the principles of traditional construction are affirmed (Obradović, 2018). The most commonly used materials for traditional construction in the past were wood, stone and earth, and in some cases even straw, chaff and mud (Obradović, 2018; Lovec, 2018), so these materials can also be used in the construction of agritourism household facilities.

The realization of some flows in the process of agritourism household preparing can be very demanding and complex. Thus, the delivery of traditional log cabins, huts, cottages, watermills, fiacres, tools and appliances for agricultural and craft production (Fig. 5, Flow 3 ) is characterized by problems and specific requirements in the process of loading, transport and unloading, in order to preserve their integrity, quality and authenticity. There is a well-known example of the Drvengrad ethno-village in Western Serbia, which is not a household but it is based on traditional architecture. The log cabins in this ethno-village are several decades old and have been delivered in the form of skeletons from various locations in the surrounding area and laid on stone foundations (Tripedia, n.d.).

Input flows of ethnographic objects (traditional clothing, footwear, furniture, tools, utensils, musical instruments, ceremonial items etc.) are intensively realized in the phase of household preparing but also later, during the period of agritourism activity, with less frequency and volume. This is especially true when there is a museum within the household that exhibits such items. Flows for the delivery of exhibits must be realized by trained persons, in accordance with the rules of handling, packaging and transportation of ethnographic museum exhibits (Shelley, 2019). 
Layout of the elements of the exterior and interior of the household should be functionally and aesthetically appropriate. Agritourism household areas and facilities may have the following functions: accommodation and meals of household members; accommodation and meals for visitors; entertainment and recreation of visitors; green areas; parking space for household members and visitors; production and storage of agricultural products, handicrafts and souvenirs; production and storage of food products for sale and consumption; storage of packaging materials and logistics units; sale of goods produced by household; storage of waste; other functions: storage of equipment and chemical agents for facilities maintenance; washing, drying and storing laundry, bedclothes, tablecloths, towels, etc.

Layout of these units within the household should enable the efficient realization of logistical flows, activities and processes within and between them. Sometimes, multiple functions can be performed in the same space, but generally, the spatial grouping of facilities that perform related functions (e.g. production of products for sale and storage of packaging material) should be pursued. On the other hand, some functions require spatial separation (e.g. livestock production facilities or waste storage place should be away from tourists' eating and lodging facilities).

\subsection{Logistics of Procurement of Goods and Natural Raw Materials for Services and Production}

Agritourism services and household production (agricultural, food, craft and souvenir production) require the procurement of natural raw materials and/ or goods. In this case too, the use of locally available and household resources should

be pursued. However, a household does not produce some products but exploits them from natural environment or buys them from different entities. The logistics of these flows vary and depend on the type of goods and participants in the supply chain.

Mushrooms, herbs, teas, flowers, wild fruits (wild strawberries, blackberries, blueberries, briar, etc.) can be harvested in nature, delivered to the household and used for consumption, processing and sale (Fig. 5, Flow 4). Territorial dispersion, inaccessibility of locations, characteristics and sensitivity of natural raw materials influence the complexity of flow realization and specific requirements from the aspect of packaging, handling and transport. Although raw materials produced or exploited from nature by the household are commonly used for the preparation of food and beverages consumed by visitors, raw materials or finished products can also be purchased from other households (Fig. 5, Flow 5) and trading companies (Fig. 5, Flow 6). Flows can be realized by (Tadić \& Veljović, 2020): household, supplier, logistics provider hired by one of the parties or participants in the crowd logistics network, i.e. other households (Carbone et al., 2017). The size and frequency of delivery of goods and materials depends on the type of goods, materials, consumption intensity, supply system, household location etc. (Tadić \& Veljović, 2020). There is the problem of optimizing the relationship between inventory costs and transportation costs. New business models are based on low inventory levels and precisely defined deliveries (JIT, Just In Time) and the pursuit of a fast response to customer demands (ECR, Efficient Consumer Response), 
which results in an increase in the frequency of smaller deliveries (Tadić \& Zečević, 2016a; 2016b). With increasing frequency of deliveries, the number of vehicle starts and vehicle-kilometers traveled increases, that is, the costs and all the negative effects of transport on the environment increase (Tadić et al., 2015; 2016a). On the other hand, households in rural areas are most often away from trading companies and other suppliers, with larger storage space, whose price is generally significantly lower than in urban areas, so in some situations it is justified to strive for less frequency and higher volume of deliveries.

Procurement of easily perishable food products that are not produced by the household requires the cold supply chain implementation (Jedermann et al., 2014; Bogataj et al., 2005). Bulk goods for food production and services, that absorb moisture (e.g. salt, sugar, flour, etc.), also make specific logistical demand to protect it. Food products should be adequately packaged, transported and stored, necessarily separated from non-food items, so that mutual contamination does not occur (Boyer \& McKinney, 2018). The size and frequency of delivery of goods should be adjusted to the needs of consumption, with the determination of an appropriate inventory level. The application of different theoretical models (Chandon \& Wansink, 2006) and modern technologies (Garg et al., 2020; Bally et al., 2013) can support effective inventory management. Procurement can also be realized with a more frequent delivery of smaller quantities of goods, without inventory holding, in order to ensure freshness and quality of food. In this case, the suppliers are usually local agricultural households.
Services and household production require appropriate hygiene conditions, namely the procurement of equipment and chemicals for personal hygiene, maintenance of the yard, facilities, furniture etc. Procurement of highly concentrated diluting chemical products reduces the cost of packaging and transportation (McCabe et al., 2008). It is especially important to separate chemical products from food products, given the potential for toxic effects. The frequency and volume of flows depend on the intensity of consumption, household capacity, characteristics of offer and demand, etc.

Agricultural, craft and souvenir production require the procurement of a variety of goods, materials: fertilizers, seeds, animal feed, logistic units for the collection and transport of agricultural products (packages, crates, sacks, etc.), packaging materials for finished products, raw or auxiliary materials for craft and souvenir production (e.g. clay for making pottery products, animal skin tanning preparations, etc.). Some of these goods and materials (e.g. concentrated fodder) require the obligatory absence of moisture, while for some (e.g. clay) the presence of moisture is desirable, but most do not make specific logistical demands. Goods and materials in this category, as well as those for food production and providing services, should be protected from harmful physical, chemical and biological influences. The frequency and volume of flows should be adjusted to the dynamics of production. Significant benefits in the utilization of means of transport can be achieved by coordinating supply flows of related goods in terms of logistics (e.g. fertilizers, seeds, fodder and cereals) (Gebresenbet \& Ljungberg, 2001). 


\subsection{Logistics of Household Production}

The logistics of agritourism household production includes the planning, organization and realization of agricultural, food, craft and souvenir production.

In the process of agricultural production, internal i.e. logistical flows within and between the units owned by the household (yard, agricultural buildings, orchards, fields, meadows, etc.) are realized (Fig. 5, Flow 7) (Tadić \& Veljović, 2020). Agricultural machinery, land, warehouses and production facilities form the material basis of agricultural production logistics. Agricultural production flows may include (Tadić \& Veljović, 2020):

- Goods, materials and freights that enable agricultural production (fences, wires, machines, tools, seeds, fertilizers, pesticides, hives, etc.);

- Agricultural products (fruits, vegetables, cereals, dairy, bee products, live animals, meat, leather, wool, feathers, etc.);

- By-products of agricultural production (manure, unusable and substandard products, other production wastes);

- Logistic and packaging units (boxes, crates, barrels, pallets, containers, etc.).

Time of realization, frequency, volume and other characteristics of the flows depend on: the activity of the household (Tadić \& Veljović, 2020), i.e. branches of agriculture (fruit growing, crop production, livestock breeding, beekeeping, fishing, cultivation of mushrooms, production of spices and medicinal herbs, etc.), intensity and production purposes (own needs, agritourism services, commercial production), technical and technological development, demographic and socioeconomic characteristics etc. Seasonality is a basic feature of agritourism offer and demand, as well as logistics of agricultural production. The most intensive agricultural production flows realize in the spring and summer. Logistics demands for the rest of the year relate mainly to the storage and inventory management.

Agricultural products can be sold or be part of agritourism services. If products are for sale, various processing and finishing operations (washing, cleaning, peeling, pitting, drying), sorting, packaging and labeling can be performed on them. In addition, agricultural products can also be raw materials for the food production (jam, pickle, cheese, cured meat products, fruit juices, liqueurs, wine, brandy, etc.), craft products (fabrics, knitwear, rugs, traditional clothing, footwear, dishes, barrels, implements, furniture, etc.) and souvenirs, which can also be sold or used in the household. Food production is based on the processing of seasonal agricultural products, so the consumption and sale of food products also usually has a seasonal character, but the storage and inventory management enable their realization throughout the year. In some cases, storage is also carried out as part of the production process (e.g. ripening of brandy and wine, drying of meat and fruit), except for the purpose of owning inventory. Some products are not produced, sold or consumed massively within the agritourism offer, despite the suitability of the area for their production, due to the lack of adequate equipment (Hüller et al., 2017). Therefore, investments in the logistics of agricultural and food production are most often focused on means of transport, storage space and packaging equipment (Rokicki, 2013). The methods of packaging and storage of agricultural and food products depend on their characteristics (Boyer \& McKinney, 
2018). The application of advanced technologies and inventory management models can also contribute to a more efficient realization of agricultural and food production (Lowe \& Preckel, 2004).

Food produced by household can be part of the food service, and craft products (furniture, dishes, tools etc.) can use as everyday items and be part of the rustic ambience in which agritourism services take place. In the production of handicrafts and souvenirs, efforts should be made to use the available local resources: wood, clay, plants, stones, fabric from our own production, natural colors etc. Souvenir packaging should: inform the buyer about the product and the manufacturer, be suitable the transportation and consumption of the product, and not endanger the environment (Qi \& Hong, 2011). As in the case of agricultural and food production, adequate space, conditions and equipment for the production and storage of handicrafts and souvenirs should be provided. A separated storage space for raw materials, packaging materials and final products should be provided, in accordance with the requirements of goods and materials.

Households can offer products with varying degrees of processing. For example, a household may sell sheep's wool, knitwear made from sheep's wool, as well as handknitted garments (hats, scarves, sweaters, gloves, skirts, socks, etc.). In this way, agricultural, handicraft and souvenir can be obtained from the same starting raw material.

In addition to products, the process of their production can be part of agritourism services (Phillip et al., 2010). By participating in household chores, visitors can have fun but also earn and acquire different knowledge and skills.

\subsection{Reverse Logistics and Waste Management}

According to The European Working Group on Reverse Logistics (as cited in De Brito \& Dekker, 2004), reverse logistics is "the process of planning, implementing and controlling the return flows of raw materials, semi-finished products, packaging and finished products, from the point of production, distribution or use to the point of renewal or proper disposal". The main factors why reverse logistics is gaining importance are (De Brito \& Dekker, 2004): social environmental awareness, the economic benefits of using returned products, and environmental laws. Realization of return flows (Fig. 5, Flow 8) and waste flows (Fig. 5, Flow 9) are important for successful and socially responsible business of agritourism households.

The business of agritourism households has a distinctly local character in terms of supply, production, service and features of tourist offer. Visitors are given an insight into all the products, entities and activities involved in the process of creating and realizing an agritourism offer ("from farm to fork"). In line with the concept of informing visitors about the origin and quality of products and the imperative of rational utilization of available resources, the agritourism household strives to simultaneously be the source of raw materials, the point of production, distribution, use, renewal and even the proper disposal of unusable products (e.g. animal dung for fertilizing land). In this case, most of the reverse logistics flows, activities and processes take place within the household. Return flows 
that are realized with suppliers of goods and materials non-produced by household, as well as flows of waste materials that cannot be rationally used in the household, are an exception. Agritourism household reverse flows may include:

- Raw materials, semi-finished and finished products, which are permanently returned to the supplier for various reasons (expired goods, inadequate quality of goods, etc.);

- Reusable products (e.g. laundry) and logistic units (pallets and minicontainers);

- Commercial returnable packaging (usually for beverages);

- Waste materials that cannot be used in the household (disposable packaging, unusable waste from agricultural production, etc.).

The goal of rural waste management is to collect it at source, recovery recyclable materials, convert organic waste into compost and safely dispose of residual waste (Majumdar, 2012). According to research, due to the development of rural tourism and agritourism waste increases which threatens the environment (Chen et al., 2018). Due to the space available, households in rural areas are suitable for sorting and long-term storage of waste (Bing et al., 2012). This allows a lower frequency of waste flows. Household waste flows can be realized by households, waste collection services or a logistics provider hired by one of the parties (Tadić \& Veljović, 2020). If household realizes the flows, the waste is delivered to the public waste receivers at bring collection sites (Beullens et al., 2004). Waste collection services realize flows from waste receivers or households, in the case of source collection, to facilities for further waste treatment. However, waste collection services are only realized for rural communities near major cities, while services typically do not cover large rural regions (Mihai \& Ingrao, 2018). Due to the lack of waste disposal infrastructure, households in rural areas often practice waste incineration or disposal at wild landfills or into rivers (Mihai, 2012). Improper waste management can cause air, water and soil pollution, unpleasant aesthetic impression, odor, but also serious health problems: infections, diseases, toxic and carcinogenic effects on the human organism (Rushton, 2003). Given that the unpolluted natural environment, clean air, healthy food and water are basic amenities that attract tourists to rural areas, improper waste management can significantly impair the quality of tourism offer. Therefore, it is necessary to involve government in the construction of adequate infrastructure for waste disposal and treatment, as well as in the education of tourist service providers.

Waste arising from providing accommodation and food services is of various types, similar in composition to municipal waste, containing articles of paper and cardboard, glass, aluminum, plastic, organic waste, construction materials and furniture, used oils and fats and other wastes (Styles et al., 2013). The options for waste management from the most desirable to the least desirable are: waste prevention, reuse, recycling, energy recovery and disposal (European Commission, 2010).

Food waste prevention is achieved by procuring the right amount of products, their proper storage and consumption (Styles et al., 2013), and by applying advanced inventory control technologies and FEFO principles (First Expired First Out), i.e. by rotation and consumption of inventories by expiration date (Jedermann et al., 2014). Although the 
using of packaging materials can contribute to product recognition and sales, the purchase of local, unpackaged agricultural products can reduce the amount of packaging waste (Styles et al., 2013; Nair \& Jayakumar, 2010). The elimination of packaging can be achieved by using a reusable logistics unit (e.g. supplying the hotel with locally produced food in reusable containers; Nair \& Jayakumar, 2010).

The reuse of old, used items, packaging of products, other discarded products from consumption and agricultural production and renewable resources contributes to the economy of households, represents an environmentally and socially responsible behavior, and encourages the sustainable development of agritourism households. The collection of metal and plastic waste by the locals, and its exchange for food products (Nair \& Jayakumar, 2010), is an example of responsible behavior and sustainable development. The rational use of resources is in line with the concept of "Zero waste", but also with tradition and cultural heritage (Nair \& Jayakumar, 2010). Therefore, the education and participation of visitors in product recovery processes can be part of an integral agritourism offer.

Agritourism household can use some of the organic waste for animal feed or composting. The compost can be used for soil fertilization. Also, the household plays a role in the cleaning, classification and preparation of waste for the recycling process (A Jalil et al., 2016).

\subsection{Logistics of Promotion, Events and Sales}

The following forms of promotion, sales and market communication are most commonly used in agritourism (Niedziółka, 2012): various types of advertising (newspapers, internet, radio and television), publications (catalogs, brochures, maps), participation in trade fairs and tourist exchanges, complementary promotion (e.g. in the form of price reductions for regular customers and friends), personal selling and various types of public relations (conferences, symposia, festivities, festivals, etc.). Promotional activities and informing tourists include logistical activities. Various definitions of logistics of the agritourism promotion are present in the literature. Kościelniak et al. (2017) and Niedziółka (2012) highlight the importance of information flows on agritourism services, while Brzozowska et al. (2018) define promotion logistics as the process of planning, executing and controlling the cost-effective flow of raw materials, materials and relevant information from place of origin to place of consumption. Information flows are realized through the use of ICT, but also through the physical distribution of promotional materials (brochures, guides, billboards, etc.) (Fig. 5, Flow 10). The flows are very frequent or continuous, in order to actively promote, inform and attract tourists. In the context of agritourism promotion logistics, cooperation between agritourism household owners and other entities in the supply chain: agritourism promotion associations, local government and agricultural advisory centers is important (Brzozowska et al., 2018). Increasing the number of institutions and entities that simultaneously carry out promotional activities increases the probability that information on agritourism services will reach potential tourists (Niedziółka, 2012).

Logistics plays a role in the participation of agritourism households at tourist and 
gastronomic fairs and events, as well as in organizing their own events and festivals. In organization and realization of such events, the principles, theoretical, technological and technical advances of event logistics and management should be applied (Minis et al., 2006; Shone \& Parry, 2004; Goldblatt, 2002; Liaudat \& Henderson, 2002). Various events and festivals can contribute to the popularity of agritourism and attract a large number of tourists (Felsenstein \& Fleischer, 2003).

Agritourism household can sell services and material products. The sale of agritourism services is usually contracted directly, by telephone conversation between homeowners and potential tourists or at agritourism fairs (Brzozowska et al., 2018), but electronic purchase of services and capacity reservations are also more prevalent (Law et al., 2015). Also, sales and promotion of tourism products can be mediated by tour operators and travel agencies (Page, 2014; Radac et al., 2013). Goods produced by agritourism household can be sold in household, agricultural, food, handicraft, souvenir shops and other trading companies (Fig. 5, Flow 11), at agritourism and gastronomic fairs and events (Fig. 5, Flow 12). Also, goods produced by household can be sold to other households (Fig. 5, Flow 13), but also as raw material to manufacturing, processing, catering companies, other rural tourism service providers etc. (Fig. 5, Flow 14). Flows of goods produced by household to companies, customers can be realized by households, companies or a logistics provider hired by one of the parties (Tadić \& Veljović, 2020). The realization of these flows also requires the realization of flows of delivery of logistic units, crates for packing goods, to the household. Agritourism can accelerate the sale of products outside the area where the household is located, as well as, conversely, the presence of these products on the market can lead customers to visit their place of production.

The packaging of goods produced by household is very important for its sale. The packaging should provide information to the customers, recognizability of the indigenous product, sustainability of its quality and possibility of proper storage. In the case of underdeveloped household production, products are often distributed to relatives and friends when not professionally packaged and labeled (Hüller et al., 2017). Product packaging management is important for the commercialization of agriculture and should be taken into account in the development of agriculture production logistics (Gebresenbet \& Bosona, 2012). The size of the packaging should be adjusted to the customer's wishes regarding the quantity of the product.

\subsection{Logistics of Agritourism Services}

Logistics plays a role in the planning, organization, realization and analysis of accommodation, food, ancillary and other agritourism services (entertainment, recreation, excursions, etc.). Logistics of accommodation services involves planning and providing conditions for day and night stay of visitors (internal transport, luggage storage, visitor accommodation, etc.). In order to provide these conditions, ancillary services are provided: cleaning, changing and washing of bedclothes and tablecloths, maintenance of electrical installations, heating, ventilation and air conditioning (HVAC) systems, etc. Ancillary services can be provided by the household (insourcing), when internal flows are realized (Fig. 5, Flow 
15), or purchased from service providers (outsourcing) (Atkin \& Brooks, 2015), when in addition to internal ones, input-output flows are realized (Fig. 5, Flow 16) (Tadić \& Veljović, 2020). Food service logistics includes activities related to the preparation, storage, serving and consumption of food and beverages. Accommodation and food services can be realized (Fig. 6):

- Centralized - in one facility (Fig. 6a);

- Decentralized - groups of tourists are accommodated in respective accommodation units (e.g. bungalows) where they are provided with food services (Fig. 6b);

- Combined - accommodation in the basic facility and respective accommodation units, meals in the dining room of the basic facility and within respective accommodation units (Fig. 6c).
A large number of agritourism households also have a picnic, barbecue area and a shared lounge, where collective lounge and meals can be realized. In accordance with the requirements, the installation and HVAC systems maintenance flows have the lowest frequency, the flows of hygienic maintenance of facilities are much more frequent, while the food service flows are the most frequent and can be realized several times a day. The frequency and size of flows also depend on the number of visitors and the characteristics of their requests (number of meals, intensity of consumption, requests for cleaning, change of bedclothes and tablecloths, etc.). The complexity and organization of internal service flows depend on the service providing system implemented. The flows are realized using of hand trolleys for luggage, food, cleaning supplies, laundry or without auxiliary means.

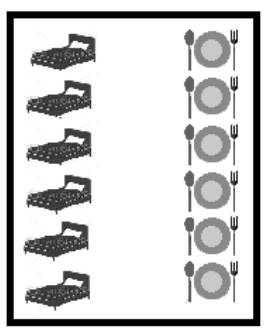

a)

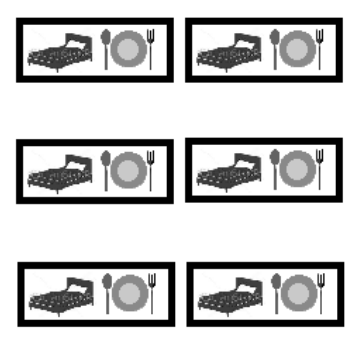

b)

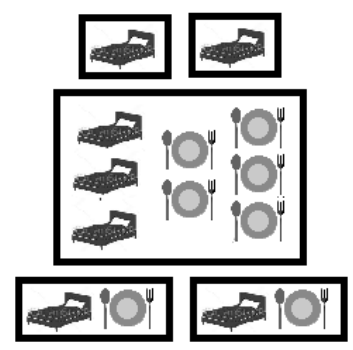

c)

Fig. 6.

Centralized (a), Decentralized (b) and Combined System (c) of Accommodation and Food Services

Other agritourism services may include a variety of amenities, activities in and outside the household: participation in agricultural, food, craft and souvenir production (picking fruits and vegetables, zootechnical activities, weaving, knitting, embroidery, food preparation etc.), health, recreational, sports, adventure, entertainment, cultural, educational activities, excursions and sightseeing tours in the vicinity of the household etc. In agritourism households, services atypical for a village setting, such as spa services (ENRD, 2016), can also be realized. The analysis of the internet offer of agritourism households services shows that in addition to accommodation and meals, the most commonly available to visitors are: cycling, walking, hiking, fishing, skiing, 
other sports and fun activities for children. The logistical demands of this category of agritourism services relate primarily to the storage and inventory management (e.g. sports equipment, books) and the organization of sightseeing tours (Fig. 5, Flow 17). For the organization of sightseeing tours, applications can be used, that generate the optimal tour based on the available time and attraction information that the user wants to visit (Brilhante et al., 2014).

\section{Conclusion}

Logistics plays a significant role in the planning, organization and realization of rural tourism and agritourism services. It provides a material and non-material basis for tourism services of households and other actors in the supply chain. The analysis of logistics flows, processes and activities in the supply chain is important both in order to can achieve the benefits in the business of tourism service providers, as well as in the context of optimizing the logistics flows of rural areas, developing their tourism offer and economy. Rural and agritourism are actively developing and gaining importance, but logistics research in these areas is very scarce, although the quality and efficiency of tourism services depend on the efficiency of logistics processes and activities in the realization of flows of people, goods and information.

This paper defines the structure of agritourism household logistics in terms of key processes, activities and links with other logistics flows generators. Also, the basic features of RTSC are presented, from the aspect of key business processes, level of development and structure. In this way, the basic goal of the paper was achieved. Structuring agritourism logistics and creating a basis for future research are the main contributions of this paper.

The analysis of rural tourism and agritourism in the context of logistics subsystems (transport, storage, inventory management, etc.) is one area for future research. Optimization of processes in particular areas of agritourism logistics, especially in the context of the relationship between transport and inventory costs, logistics costs and quality of tourist offer, can also be the subject of research. Finally, the logistics of other entities in the RTSM (suppliers of products and services, natural and cultural-historical attractions, etc.) and their relationship with agritourism households should also be the subject of scientific attention.

\section{References}

A Jalil, E. E.; Grant, D. B.; Nicholson, J. D.; Deutz, P. 2016. Reverse logistics in household recycling and waste systems: a symbiosis perspective, Supply Chain Management 21(2): 245-258.

Adamchevskaya, V. 2016. Logistic complex as agrotourism development mechanism, Quarterly Research and Practice Journal 4(24): 4-7.

Ajagunna, I.; Pinnock, F.; Amode, T. M. 2017. Tourism development and logistics in the Caribbean: will there be a symbiotic relationship? Worldwide Hospitality and Tourism Themes 9(1): 116-123.

Alegre, J.; Pou, L. 2006. The length of stay in the demand for tourism, Tourism Management 27(6): 1343-1355.

Atkin, B.; Brooks, A. 2015. Total Facility Management, John Wiley \& Sons, USA, 406 p.

Bally, B.; Peterson, G.; Stoiber, A. 2013. Household Inventory Management System. Faculty of the Electrical and Computer Engineering Technology, University of Cincinnati, USA. 
Baloglu, S.; Mangaloglu, M. 2001. Tourism destination images of Turkey, Egypt, Greece, and Italy as perceived by US-based tour operators and travel agents, Tourism Management 22(1): 1-9.

Bethapudi, A. 2013. The role of ICT in tourism industry, Journal of Applied Economics and Business 1(4): 67-79.

Beullens, P.; Van Oudheusden, D.; Van Wassenhove, L. N. 2004. Collection and Vehicle Routing Issues in Reverse Logistics, In Dekker, R.; Fleischmann, M.; Inderfurth, K.; Van Wassenhove L. N. (Ed.) Reverse Logistics: 95-134.

Bing, X.; Bloemhof-Ruwaard, J. M.; Van der Vorst, J. G. A. J. 2012. Sustainable reverse logistics network design for household plastic waste, Flexible Services and Manufacturing Journal 26(1-2): 119-142.

Bogataj, M.; Bogataj, L.; Vodopivec, R. 2005. Stability of perishable goods in cold logistic chains, International Journal of Production Economics 93: 345-356.

Boon-itt, S.; Pongpanarat, C. 2011. Measuring Service Supply Chain Management Processes: The Application of the Q-Sort Technique, International Journal of Innovation, Management and Technology 2(3): 217-221.

Boyer, R.; McKinney, J. 2018. Food Storage Guidelines For Consumers, Publication 348-960. Virginia Cooperative Extension, Virginia Tech, Virginia State University, USA.

Brilhante, I..; Macedo, J. A.; Nardini, F. M.; Perego, R.; Renso, C. 2014. TripBuilder: A Tool for Recommending Sightseeing Tours, Advances in Information Retrieval: 771-774.

Brzozowska, A.; Kalinichenko, A.; Niedziółka, A.; Popławski, $€$. 2018. Logistic procedures in the promotion of agritourism, Infrastructure and Ecology of Rural Areas 4(1): 891-907.
Buhalis, D.; Laws, D. 2001. Tourism distribution channels: Practices, issues and transformations, London: Continuum International Publishing Group, UK, 400 p.

Carbone, V.; Roquet, A.; Roussat, C. 2017. The Rise of Crowd Logistics: A New Way to Co-Create Logistics Value, Journal of Business Logistics 38(4): 238-252.

Chandon, P.; Wansink, B. 2006. How Biased Household Inventory Estimates Distort Shopping and Storage Decisions, Journal of Marketing 70(4): 118-135.

Chen, I. J.; Paulraj, A. 2004. Understanding supply chain management: critical research and a theoretical framework, International Journal of Production Research 42(1): 131-163.

Chen, J.; Guan, J.; Xu, J.; Clergeau, C. 2018. Constructing the Green Supply Chain for Rural Tourism in China: Perspective of Front-Back Stage Decoupling, Sustainability 10(11): 4276-4293.

Ciolac, R.; Adamov, T.; Iancu, T.; Popescu, G.; Lile, R.; Rujescu, C.; Marin, D. 2019. Agritourism - A Sustainable Development Factor for Improving the "Health" of Rural Settlements. Case Study Apuseni Mountains Area, Sustainability 11(5): 1467-1490.

Cooper, M.C.; Lambert, D. M.; Pagh J. D. 1997. Supply Chain Management: More Than a New Name for Logistics, The International Journal of Logistics Management 8(1): 1-14.

De Brito, M. P.; Dekker, R. 2004. A Framework for Reverse Logistics, In Dekker, R.; Fleischmann, M.; Inderfurth, K.; Van Wassenhove L. N. (Ed.), Reverse Logistics: 3-27.

Ellram, L. M.; Tate, W. L.; Billington, C. 2004. Understanding and Managing the Services Supply Chain, The Journal of Supply Chain Management 40(4): 17-32. 
European Commission. 2010. Life cycle thinking and assessment for waste management, Available from internet: <https://op.europa.eu/en/publicationdetail/-/publication/92b3f3ea-4a33-4c2b-a36968b2ea0e40ad/language-en $>$.

European Network for Rural Development (ENRD). 2016. Boerderij Spa - The farm spa, Available from internet: <https://enrd.ec.europa.eu/projects-practice/ boerderij-spa-\%E2\%80\%93-farm-spa_en $>$.

Eurostat. 2019. Nights spent at tourist accommodation establishments by degree of urbanisation (from 2012 onwards), Available from internet: <https://ec.europa. eu/eurostat $/ \mathrm{tgm} /$ refreshTableAction.do?tab=table \&p lugin $=1 \&$ pcode $=$ tin00179\&language $=e n>$.

Fagioli, F. F.; Diotallevi, F.; Ciani, A. 2014. Strengthening the sustainability of rural areas: the role of rural tourism and agritourism, Rivista di Economia Agraria 69(2-3): 155-169.

Felsenstein, D.; Fleischer, A. 2003. Local Festivals and Tourism Promotion: The Role of Public Assistance and Visitor Expenditure, Journal of Travel Research 41(4): 385-392.

Font, X.; Tapper, R.; Schwartz, K.; Kornilaki, M. 2008. Sustainable supply chain management in tourism, Business Strategy and the Environment 17(4): 260-271.

Gannon, A. 1994. Rural Tourism as a Factor in Rural Community Economic Development for Economies in Transition, Journal of Sustainable Tourism 2(1-2): 51-60.

Garg, L.; Ramesh, K.; Garg, G.; Portelli, A.; Jamal, A. 2020. Kitchen Genie: An Intelligent Internet of Things System for Household Inventory Management, In Singh, P.K.; Panigrahi, B.K.; Suryadevara, N.K.; Sharma, S.K.; Singh, A.P. (Ed.). In Proceedings of ICETIT 2019. Lecture Notes in Electrical Engineering, Institute of Information Technology \& Management, New Delhi, India, 3-20.
Gebresenbet, G; Bosona, T. 2012. Logistics and Supply Chains in Agriculture and Food, In Groznik, A. (Ed.), Pathways to Supply Chain Excellence Chapter 8: 125-146.

Gebresenbet, G.; Ljungberg, D. 2001. Coordination and Route Optimization of Agricultural Goods Transport to attenuate Environmental Impact, IT-Information Technology and the Human Interface, Journal of Agricultural Engineering Research 80(4): 329-342.

Goldblatt, J. J. 2002. Special Events: Twenty-First Century Global Event Management. The Wiley Event Management Series, Third edition, John Wiley \& Sons, Inc., USA, $488 \mathrm{p}$.

Guo, X.; He, L. 2012. Tourism Supply-Chain Coordination: The Cooperation between Tourism Hotel and Tour Operator, Tourism Economics 18(6): 1361-1376.

Hüller, S.; Heiny, J.; Leonhäuser, I.-U. 2017. Linking agricultural food production and rural tourism in the Kazbegi district - A qualitative study, Annals of Agrarian Science 15(1): 40-48.

Jedermann, R.; Nicometo, M.; Uysal, I.; Lang, W. 2014. Reducing food losses by intelligent food logistics, Philosophical Transactions of the Royal Society A: Mathematical, Physical and Engineering Sciences 372: 1-20.

Kastenholz, E.; Lopes de Almeida, A. 2008. Seasonality in rural tourism - the case of North Portugal, Tourism Review 63(2): 5-15.

Kizos, T.; Iosifides, T. 2007. The contradictions of agrotourism development in Greece: evidence from three case studies, South European Society and Politics 12: 59-77.

Kochadze, T.; Dangadze, I.; Zaqareishvili, V. 2013. The role of logistics in the market for transportation and tourist services, Machines, Tehnologies, Materials 4: 1-3. 
Kościelniak, H.; Skowron-Grabowska, B.; Nowodziński, P. 2017. Entrepreneurship and innovation in the perspective of strategic management [In Polish: Przedsiębiorczość i innowacyjność w perspektywie zarządzania strategicznego], In D. Jelonek, F. Bylok (Ed.) Multidimensionality of contemporary organization management [In Polish: Wielowymiarowość wspótczesnego zarządzania organizacjami]. Faculty of Management, Czestochowa University of Technology, Poland, 13-21.

Krasavac, B.C.; Radosavljević, K.; Bradić-Martinović, A. 2018. SWOT Analysis of the Rural Tourism as a Channel of Marketing for Agricultural Products in Serbia, Economics of Agriculture 65(2): 1573-1584.

Lambert, D. M.; Cooper, M. C.; Pagh, J. D. 1998. Supply Chain Management: Implementation Issues and Research Opportunities, The International Journal of Logistics Management 9(2): 1-20.

Lane, B. 1994. What is rural tourism? Journal of Sustainable Tourism 2(1-2): 7-21.

Law, R.; Leung, R.; Lo, A.; Leung, D.; Fong, L. H. N. 2015. Distribution channel in hospitality and tourism, International Journal of Contemporary Hospitality Management 27(3): 431-452.

Liaudat, C.; Henderson, N. 2002. Large event logistical and support traffic management, In Proceeding to 2 nd Swiss Transport Research Conference, Ascona, Switzerland.

Liu, A. 2006. Tourism in rural areas: Kedah, Malaysia, Tourism Management 27(5): 878-889.

Lovec, V. 2018. Energy performances of the traditional rammed earth house in Vojvodina [In Serbian: Energetske performanse tradicionalne vojvođanske kuće od naboja], $\mathrm{PhD}$, University of Belgrade, Faculty of Architecture, Serbia.

Lowe, T. J.; Preckel, P. V. 2004. Decision Technologies for Agribusiness Problems: A Brief Review of Selected Literature and a Call for Research, Manufacturing \& Service Operations Management 6(3): 201-208.
Majumdar, A. 2012. Rural Solid Waste Management: Issues \& Action. Available from internet: <https:// www.researchgate.net/profile/Pravash Moharana/publication/265413674_Rural_ Solid_Waste_Management_Issues_and_Action/ links/540e55cd0cf2d8daaacd46bb.pdf $>$.

Malone, T. W. 1987. Modeling Coordination in Organizations and Markets, Management Science 33(10): 1317-1332.

McCabe, S.; Clement, S.; Ochoa, A. 2008. Sustainable Procurement Guidelines for Cleaning Products and Services. - Local Governments for Sustainability (ICLEI) for the United Nations Environment Programme - Division of Technology, Industry and Economics (UNEP-DTIE). Available from internet: <https://www.greeningtheblue.org/sites/default/files/ Backgroundoncleaningproducts_0.pdf $>$.

Mehdi, S. A. 2017. Sustainable Supply Chain Management in Pithoragarh: Prospects of Rural Tourism, The IUP Journal of Supply Chain Management 14(1): 16-31.

Mihai, F.C. 2012. Improper household waste disposal in rural territory. Case Study: Neamt County, Romania, Bulletin USAMV Agriculture 69(2):15-20.

Mihai, F.-C.; Ingrao, C. 2018. Assessment of biowaste losses through unsound waste management practices in rural areas and the role of home composting, Journal of Cleaner Production 172: 1631-1638.

Minghetti, V. 2003. Building customer value in the hospitality industry: towards the definition of a customer-centric information system, Information Technology and Tourism 6(2): 141-152.

Minis, I.; Paraschi, M.; Tzimourtas, A. 2006. The design of logistics operations for the Olympic Games, International Journal of Physical Distribution \& Logistics Management 36(8): 621-642.

\section{jitte 347}


Molina, M. E. R.; Saura, I. G.; Velazquez, B. M. 2010. Information and communication technologies in rural hotels, International Journal of Sustainable Economy 2(1): 1-15.

Mrnjavac, E.; Ivanovic, S. 2007. Logistics and logistics processes in a tourism destination, Tourism and hospitality management 13(3): 531-546.

Muhcina, S.; Popovici, V. 2008. Logistics and Supply Chain Management in Tourism [In Romanian: Logistica şi managementul lanțului de aprovizionare-livrare în turism], Amfiteatru Economic 24: 122-132.

Nair, S.; Jayakumar, C. 2010. A Handbook for Waste Management in Rural Tourism Areas: A Zero Waste Approach. Available from internet: <http://chm. pops.int/Portals/0/download.aspx?d=UNEP-POPSBATBEPWK1-CS08.English.pdf>.

Niedziółka, A. 2012. Logistics in chosen institutions and entities activities in the sphere of agritourism promotion on the example of Malopolska Voivodeship [In Polish: Logistyka w działaniach wybranych podmiotów i instytucji w sferze promocji agroturystyki na przykładzie województwa małopolskiego], Logistyka 4: 1135-1142.

Niedziółka, A. 2015. Transfer of information in agritourism using portals as parts of the logistics management of rural areas, In: Brzozowska, A., Kalinichenko, A.V. (Ed.), Transformation management of economic at rural areas, Chapter 21, Poltava State Agrarian Academy, 223-230.

Nilsson, P. A. 2002. Staying on farms - an ideological background, Annals of Tourism Research 29(1): 7-24.

Obradović, T. 2018. Principles of architectural heritage and their contemporary implementation [In Serbain: Načela graditeljskog predanja i njihova savremena primena], $\mathrm{PhD}$, University of Belgrade, Faculty of Architecture, Serbia.
Ohe, Y. 2008. Characteristics and issues of rural tourism in Japan, In Brebbia, C. A.; Pineda, F. D. (Ed.) Sustainable Tourism III, Southampton: WIT Press, 305-316.

Özgener, Ş.; İraz, R. 2006. Customer relationship management in small-medium enterprises: The case of Turkish tourism industry, Tourism Management 27(6): 1356-1363.

Page, S. J. 2014. Tourism management: Managingfor change, Routledge, UK, 400 p.

Park, D. B.; Yoon, Y. S. 2009. Segmentation by motivation in rural tourism: A Korean case study, Tourism Management 30(1): 99-108.

Petrović, M. 2014. Quality of agritourism in Vojvodina and its impact on residents' attitudes, $\mathrm{PhD}$, Department of Geography, Tourism and Hotel Management, Faculty of Sciences, University of Novi Sad, Serbia.

Phillip, S.; Hunter, C.; Blackstock, K. 2010. A typology for defining agritourism, Tourism Management 31(6): 754-758.

Qi, Z.; Hong, L. 2011. Study on Design and Research of Tourist Souvenirs on the Background of Low-carbon Economy, Energy Procedia 5: 2416-2420.

Radac, B. A.; Cszos, I.; Merce, I. I.; Milin, I. A.; Zamfir, R.; Horvãth, J. 2013. The role of tourism agents in promoting rural tourism, Lucrări Științifice, Seria I, 15(4): 263-266.

Rigby, D. K.; Reicheld, F. F.; Schefter, P. 2002. Avoid the four perils of CRM, Harvard Business Review 80(2): 101-109.

Roget, F. M.; González, X. A. R. 2006. Rural Tourism Demand in Galicia, Spain, Tourism Economics 12(1): 21-31. 
Rokicki, T. 2013. The Importance of Logistics in Agribusiness Sector Companies in Poland, In Proceedings of the International Scientific Conference Economic Science for Rural Development, Jelgava 2013, 116-120.

Rushton, L. 2003. Health hazards and waste management, British Medical Bulletin 68(1): 183-197.

Ryals, L.; Knox, S. 2001. Cross-functional issues in the implementation of relationship marketing through customer relationship management, European Management Journal 19(5): 534-542.

Sengupta, K.; Heiser, D. R.; Cook, L. S. 2006. Manufacturing and Service Supply Chain Performance: A Comparative Analysis, The Journal of Supply Chain Management 42(4): 4-15.

Sharpley, R.; Roberts, L. 2004. Rural tourism - 10 years on, International Journal of Tourism Research 6(3): 119-124.

Shelley, M. 2019. The Care and Handling of Art Objects: Practices in The Metropolitan Museum of Art (revised edition, 2019). Available from internet: <https://www. metmuseum.org/art/metpublications/The_Care_ and_Handling_of_Art_Objects_Practices_in_The Metropolitan_Museum_of_Art_2019>.

Shone, A.; Parry, B. 2004. Successful Event Management: A Practical Handbook, Cengage Learning Business Press.

Sigala, M. 2008. A supply chain management approach for investigating the role of tour operators on sustainable tourism: the case of TUI, Journal of Cleaner Production 16(15): 1589-1599.

Slusarczyk, B.; Smolag, K.; Kot, S. 2016. The supply chain of a tourism product, Актуальні проблеми економіки 5: 197-207.

Song, H. 2012. Tourism Supply Chain Management. 1st Edition, Routledge, UK. 206 p.
Sonnino, R. 2004. For a "Piece of Bread"? Interpreting Sustainable Development through Agritourism in Southern Tuscany, Sociologia Ruralis 44(3): 285-300.

Styles, D.; Schönberger, H.; Martos, J. L. G. 2013. Best Environmental Management Practice in the tourism sector, Europian Commision. Available from internet: <http://susproc.jrc.ec.europa.eu/activities/emas/ documents/TourismBEMP.pdf $>$.

Tadić, S.; Veljović, M. 2020. Logistics flows of household, Tehnika 75(2): 225-237.

Tadić, S.; Zečević, S. 2016b. Global trends and their impact on city logistics management, Tehnika 66(3): 459-464.

Tadić, S.; Zečević, S.; Krstić, M. 2012. Logistics and Supply Chain Managmant in tourism: Present state and limitations, Tehnika 67(6): 1018-1025.

Tadić, S.; Zečević, S.; Krstić, M. 2015. City logistics - status and trends, International journal for traffic and transport engineering 5(3): 319-343.

Tadić, S.; Zečević, S. 2016a. Modeling of the city logistics conceptions [In Serbian: Modeliranje koncepcija city logistike]. University of Belgrade, Faculty of Transport and Traffic Engineering, Serbia, 358 p.

Tadić, S.; Zečević, S.; Krstić, M. 2014. City logistics initiatives aimed at improving sustainability by changing the context of urban area [In Serbian: Inicijative city logistike u cilju poboljšanja održivosti promenom konteksta urbane sredine], Tehnika 61(5): 834-843.

Tanasă, L. 2014. Benefits Of Short Food Supply Chains For The Development Of Rural Tourism In Romania As Emergent Country During Crisis, Agricultural Economics and Rural Development 11(2): 181-193. 
Tapper, R.; Font, X. 2004. Tourism supply chains: Report of a desk research project for the travel foundation, Environment Business \& Development Group, Leeds Metropolitan University.

TRIP. 2019. Rural Connections: Challenges and Opportunities In America's Heartland. Available from internet: <https://tripnet.org/wp-content/ uploads/2019/08/Rural_Roads_TRIP_Report May_2019.pdf>.

Tripedia, no date. Drvengrad. Available from internet: $<$ https://tripedia.info/attraction/drvengrad-serbia/>.

Ujma, D. 2001. Distribution channels for tourism: theory and issues, In Buhalis, D.; Laws, E. (Ed.), Tourism distribution channels: Practices, issues and transformations, London: Continuum International Publishing Group, $33-52$.

United Nations (UN). 2010. International Recommendations for Tourism Statistics 2008. Available from internet: <https://unstats.un.org/unsd/ publication/seriesm/seriesm_83revle.pdf $>$.
Vuković, P. 2017. Character and Dynamics of Development Rural Tourism in the Republic of Serbia, Ekonomika - Journal for Economic Theory and Practice and Social Issues 63(4): 53-60.

Xu, H.; Zhou, X. 2009. The construction of conceptual model of tourist destination supply chain, Tourism Science 23: 15-20.

Zečević, S.; Tadić, S. 2006. City logistics [In Serbian: City logistika]. University of Belgrade, Faculty of Transport and Traffic Engineering, Serbia, 190 p.

Zeithaml, V. A.; Parasuraman, A.; Berry, L. L. 1985. Problems and Strategies in Services Marketing, Journal of Marketing 49(2): 33-46.

Zhang, X.; Song, H.; Huang, G. 2009. Tourism supply chain management: A new research agenda, Tourism Management 30: 345-358. 